\title{
WYKAZ PRAC DYPLOMOWYCH NAPISANYCH POD KIERUNKIEM KS. PROF. DR. HAB. AUGUSTYNA ECKMANNA
}

\section{A. Prace doktorskie}

1. Pająk I., Społeczności w „De civitate Dei” świętego Augustyna, 1997.

2. Gacia T., Motyw męczeństwa w twórczości świętego Ambrożego, 1998.

3. Wójtowicz Z., Kultura klasyczna w twórczości Salwiana z Marsylii, 2000.

4. Krynicka T., Świat przyrody w XVII księdze „Etymologii” Izydora z Sewilli, 2005.

5. Sarzyńska B., Świat pogański i chrześcijański w „, Res Gestae” Ammiana Marcelina, 2009.

6. Laskowski Ł., Pseudo-Filona „Liber Antiquitatum Biblicarum” w kontekście starożytnej tradycji grecko-rzymskiej, 2010.

7. Baran G., Motyw synostwa Bożego w „In Iohannis Evangelium Tractatus” oraz „In Iohannis Epistolam ad Parthos Tractatus” świętego Augustyna, 2010.

8. Maćkowska A., Obraz kobiety w pismach św. Augustyna. Od rzeczywistości do symbolu, 2012.

9. Wójcik G., Obraz kobiety w „Annales seu Cronicae Incliti Regni Poloniae” Jana Dtugosza, 2014.

\section{B. Prace magisterskie}

1. Niklewicz D., Stosunek Chrystusa do spoczynku sabatowego na tle ówczesnych zwyczajów na podstawie logionów Mk 2, 27. 28, 1897.

2. Grabowski P., Wolność w świetle Ewangelii św. Jana 8, 32-36 i paralelnych tekstów św. Pawła Rz 8, 21; 1Kor 7, 22; 2 Kor 3, 17, 1988.

3. Kamiński L., Wierność Boga jako motyw historiozbawczy na podstawie 2Tm 2, $13,1988$.

4. Kotłowski Z., Nowość nauki Jezusa Chrystusa w oparciu o Mk 1, 27, 1988.

5. Zalewski D., Wewnętrzne pouczenie jako znak Nowego Przymierza w I Liście św. Jana 2, 27,1988.

6. Nowakowski B., Głoszenie Ewangelii przez św. Pawła jako objawienie Jezusa Chrystusa na podstawie Ga 1, 16, 1989.

7. Tusk J., Języki ogniste i ich symbolika w Dz 2, 3-4 w oparciu o Stary Testament, 1989.

8. Aniołkowski D., Współczesne rozumienie postu w świetle nauki świętego Augustyna o człowieku, 1990.

9. Bystroń J., Nauka o śmierci w „Enarrationes in Psalmos” świętego Augustyna, 1990.

10. Chuchała W., Znaczenie „Eneidy” Wergiliusza w „De civitate Dei” św. Augustyna, 1990. 
11. Hoppe B., Polemika św. Augustyna z donatystami w świetle ,, Sermo ad Caesariensis Ecclesiae plebem", 1990.

12. Kitowski H., Nauka o pokorze w „,Enarrationes in Psalmos” św. Augustyna, 1990.

13. Dudziński J., Stosunek papieża Grzegorza Wielkiego do Żydów w świetle jego korespondencji, 1991.

14. Jabłońska U., Obraz bóstw żeńskich w „De civitate Dei” św. Augustyna, 1991.

15. Kiedrowicz W., Rozumienie „dążenia do świętości” w listach św. Hieronima, 1991.

16. Meger E., „Actio” $i$ „,contemplatio” $w$ dialogach filozoficznych św. Augustyna, 1991.

17. Pająk I., Obraz pogańskiego społeczeństwa rzymskiego $w$ „,De civitate Dei” św. Augustyna, 1991.

18. Tisler P., Obecność Wergiliusza w dialogach z Kasycjakum świętego Augustyna, 1991.

19. Widok N., Eklektyzm filozofii w pismach Klemensa Aleksandryjskiego, 1991.

20. Kuzyński M., Percepcja nauki św. Augustyna o Kościele w konstytucji soborowej „Lumen gentium”, 1992.

21. Okrój A., Zagadnienia eschatyczne w listach egzegetycznych św. Hieronima, 1992.

22. Wróbel Z., Aurelius Augustinus, „,De patientia”. Wstęp i przekład, 1992.

23. Gorycka L., Obraz dziecka w „, Confessiones” i dialogach filozoficznych św. Augustyna, 1993.

24. Labuhn M., Nauka o cierpieniu w „De civitae Dei” świętego Augustyna, 1993.

25. Bienias W., Aurelius Augustinus, „De fide et Symbolo”. Wstęp, przekład, komentarz, 1994.

26. Kaiser G., Percepcja nauki Ojców Kościoła w konstytucji soborowej „Dei verbum”, 1994.

27. Kwiatkowski J., Ksiądz Wacław Eborowicz jako patrolog, 1994.

28. Kwiatkowski M., Święty Augustyn w życiu i myśli I.H. Neumana, 1994.

29. Pielecki W., Nauka o człowieku w „Enarrationes in Psalmos” świętego Augustyna, 1994.

30. Gacia T., Aurelius Augustinus, „De bono viduitatis”. Wstęp, przekład, komentarz, 1995.

31. Kociniewski P., Percepcja pism świętego Ambrożego w czytaniach brewiarzowych, 1995.

32. Kościelniak K., Aurelius Augustinus, „De nuptiis et concupiscentia”. Wstęp, przekład, komentarz do księgi pierwszej, 1995.

33. Laskowski S., Aurelius Augustinus, „De continentia”. Wstęp, przekład, komentarz, 1995.

34. Nazaruk E., Dziewictwo, matżeństwo, rodzina $w$ „Enarrationes in Psalmos” św. Augustyna, 1995.

35. Wójtowicz Z., Rufinus Tyrannius, „Expositio Symboli”. Wstęp, przekład, komentarz, 1995.

36. Cieśluk M., Aurelius Augustinus, „De coniugiis adulterinis” liber secundus. Wstep, przekład, komentarz, 1996.

37. Damian J.M., Aurelius Augustinus, „De coniugiis adulterinis” liber primus. Wstę, przekład, komentarz, 1996. 
38. Szram M., Alegorie mądrości Bożej w pismach Orygenesa, 1996.

39. Kozińska J., Motyw ,drogi” w ,,Enarrationes in Psalmos” św. Augustyna, 1997.

40. Stranc A.T., Człowieczeństwo Jezusa Chrystusa w świetle „Enarrationes in Psalmos" św. Augustyna, 1997.

41. Cieszyński R., Śmierć w świetle „De civitate Dei” świętego Augustyna, 1998.

42. Draws A., Kardynalna cnota umiarkowania w życiu kapłańskim wedtug „,De officiis ministrorum" św. Ambrożego, 1998.

43. Felski W., Teologiczne znaczenie odniesień Wergiliańskich $w$ listach św. Hieronima, 1998.

44. Filipowicz A., Motyw śmierci w „, Orationes funebres” św. Ambrożego, 1998.

45. Jurkiewicz J., Motyw pokory w „Expositio Evangelii secundum Lucam” św. Ambrożego, 1998.

46. Kwasigroch B., Zmartwychwstanie w świetle „De civitate Dei” świętego Augustyna, 1998.

47. Słomińska K., Motyw „,matki” w „Expositio Evangelii secundum Lucam” św. Ambrożego, 1998.

48. Smętek A., Aurelius Ambrosius, „,De viduis”. Wstęp, przekład, komentarz, 1998.

49. Wera M., Rady ewangeliczne w listach świętego Hieronima, 1998.

50. Bobel R., Aurelius Augustinus, „,De sancta virginitate”. Rpzdz. 1.1-30.30. Wstęp, przekład, komentarz, 1999.

51. Bojko H., Aurelius Augustinus, „De sancta virginitate”. Capita 31.31-58.57. Wstę, przekład, komentarz, 1999.

52. Haase J., Motywy antyczne w poezji Romana Brandstaettera, 1999.

53. Labuda M., Obraz grzechu w ,Enarrationes in Psalmos” św. Augustyna, 1999.

54. Majcher M., Aurelius Augustinus, „,Epistola 185. De correctione Donatistarum liber”. Wstęp, przekład, komentarz, 1999.

55. Ziętal M., Aurelius Augustinus, „Epistola 187. De praesentia Dei liber”. Wstęp, przekład, komentarz, 1999.

56. Cała L., Czyściec w nauczaniu Ojców Kościoła, 2000.

57. Galikowski T., Motyw dnia w „Enarrationes in Psalmos” świętego Augustyna, 2000.

58. Dułak T., Obraz człowieka $w$ dialogach filozoficznych św. Augustyna, 2001.

59. Jaśkiewicz G., Motyw radości w „, Enarrationes in Psalmos” św. Augustyna, 2001.

60. Laniecki M., Pożąlliwość w świetle pism św. Augustyna ze szczególnym uwzglednieniem ,Enarrationes in Psalmos”, 2001.

61. Baj T., Obraz kaznodziei w „De doctrina christiana” św. Augustyna, 2002.

62. Dominik K., Pawłowa wizja chrześcijańskiej wspólnoty na podstawie Listu do Filipian, UKSW Warszawa 2002.

63. Dudek R., Szatan w ,Enarrationes in Psalmos” świętego Augustyna, 2002.

64. Glaza M., Moralna ocena czynów ludzkich w dziele św. Ambrożego „,De poenitentia”, 2002.

65. Krzyszkowski Z., Bóg w „, Confessiones” św. Augustyna, 2002.

66. Lal M., Grzech w „Enarrationes in Psalmos” św. Augustyna, 2002.

67. Ołdakowska A., Bóstwa meskie w „De civitate Dei” św. Augustyna, 2002.

68. Sosnowski J., Świętość w świetle „Enarrationes in Psalmos” świętego Augustyna, 2002. 
69. Węsierski M., Motyw męczeństwa w „Enarrationes in Psalmos” świętego Augustyna, 2002.

70. Bekisch P., Najprzedniejsze dobre uczynki w „Enarrationes in Psalmos ” świętego Augustyna, 2003.

71. Brzeziecka K., Niewolnicy w świetle pism Seneki Młodszego oraz Pawła z Tarsu, 2003.

72. Brzozowiec-Wysokińska B., Obraz człowieka w „Listach moralnych do Lucyliusza” Seneki, 2003.

73. Kwaśny E., Portret Aleksandra Wielkiego i Juliusza Cezara w Żywotach Równolegtych Plutarcha, 2003.

74. Machnacz M., Obraz obyczajów i wierzeń Germanów jako przodków Wikingów na podstawie „De origine et situ” Tacyta i źródet średniowiecznych, 2003.

75. Malicka M., Motyw Światła i Życia w komentarzach świętego Augustyna do pism Janowych, 2003.

76. Michalczewska M., Koncepcja szczęścia w świetle dialogów filozoficznych Seneki Młodszego, 2003.

77. Szymańska M., Motyw matki w ,Enarrationes in Psalmos” św. Augustyna, 2003

78. Głogowski W., Tajemnica Jezusa Chrystusa w dziele „De principiis” Orygenesa, 2004.

79. Knopik W., Święta Monika jako żona i matka w świetle ,, Wyznań” świętego Augustyna, 2004.

80. Kubiak J., Odpuszczenie grzechów w Kościele w świetle „De poenitentia” św. Ambrożego, 2004.

81. Sadowska-Błażewicz D., Hannibal-taktyka i działania w przeddzień wybuchu II wojny punickiej w świetle XXI księgi „, Ab Urbe condita” Tytusa Liwiusza, 2004.

82. Chrzanowska K., Sylwetki rzymianek w pismach Tacyta i Swetoniusza, 2005.

83. Kamiński K., Kapłan-duszpasterz w świetle „De sacerdotio” świętego Jana Chryzostoma, 2005.

84. Kowalska A., Motyw męczeństwa w pismach apologetycznych Tertuliana, 2005.

85. Lipka M., Wizerunek kobiety w korespondencji świętego Hieronima, 2005.

86. Sakowicz A., Motywy konsolacyjne w dialogach i listach Seneki, 2005.

87. Smoleń A., Autorzy klasyczni w korespondencji świętego Hieronima ze Strydonu, 2005.

88. Urban A., Postać św. Agnieszki w pismach łacińskich autorów wczesnochrześcijańskich.

89. Wójcik M., Erazm z Rotterdamu jako propagator kultury antycznej, 2005.

90. Kaczmarek D.A., Providentia Dei w pismach Lucjusza Anneusza Seneki i Tomasza a Kempis, 2006.

91. Kochańska S., Oblicza miłości u Seneki Młodszego, 2006.

92. Maćkowska A., Człowiek w życiu prywatnym i państwowym w „Epistulae morales ad Lucilium” Lucjusza Anneusza Seneki, 2006.

93. Osowski K., Małżeństwo i dziewictwo w świetle „Enarrationes in Psalmos” św. Augustyna, 2006.

94. Ossowski K., Motyw dziewictwa w świetle „De virginibus” świętego Ambrożego, 2006.

95. Piasecki D., Życie i śmierć w „Listach moralnych do Lucyliusza” L.A. Seneki, 2006. 
96. Synoradzki Ł., Grzech i śmierć w katechezach przedchrzcielnych i mistagogicznych świętego Cyryla Jerozolimskiego, 2006.

97. Wawrzynkowski M., Obraz Boga w'świetle „,De principiis” Orygenesa, 2006.

98. Wąsik A.W., Druidzi w świetle tekstów autorów łacińskich, 2006.

99. Socha K., Przyjaźń w korespondencji Pliniusza Młodszego, 2007.

100. Tymoczko K., Lucjusz Anneusz Seneka w świetle swoich listów, 2007.

101. Zajączkowska T., Profesor Leokadia Małunowiczówna jako filolog klasyczny, 2007.

102. Dykowski P., Motywy antyczne w pismach biskupa Romana Andrzejewskiego, 2008.

103. Kątny Ł., Tajemnica Ducha Świętego w świetle „De principiis” Orygenesa, 2008 .

104. Michalska B., Attyla wświetle pism późnego antyku i wczesnego średniowiecza, 2008.

105. Strankowski M., Obecność poetów epoki augustowskiej w listach św. Hieronima ze Strydonu, 2008.

106. Suska E.A., Virtus w „De civitate Dei” świętego Augustyna, 2008.

107. Zaremba S., Znaczenie terminu „,perseverantia” $w$ traktacie „De bono perseverantiae”'św. Augustyna, 2008.

108. Afonin Y., Reminiscencje Kanonu Rzymskiego w Anaforze świętego Jana Chryzostoma, 2009.

109. Baran G., Motyw uzdrowienia w świetle dziet świętego Augustyna „In Iohannis Evangelium Tractatus” oraz „In Iohannis Epistolam ad Parthos Tractatus”, 2009.

110. Kłosowski M., Kościót w świetle „Listów” świętego Ignacego Antiocheńskiego, UKSW Warszawa, 2009.

111. Bielicki T., Antropologia duchowa wświetle „,De principiis” Orygenesa, 2010.

112. Cieszyński M., Dobro w świetle „Enarrationes in Psalmos” świętego Augustyna, 2010.

113. Kasprzak P., Motywy antyczne w poezji Marii Pawlikowskiej-Jasnorzewskiej, 2010.

114. Markiewicz M., Pisarze antyczni w „, Confessiones” świętego Augustyna, 2010.

115. Radziuk I., Własność prywatna w świetle dziet św. Ambrożego, 2010.

\section{Prace licencjackie}

1. Grzywaczewska A., Kultura wsi poleskiej na przełomie XIX i XX wieku na podstawie wybranych źródet i opracowań, 2009.

2. Guziak E., Sztuka lekarska w starożytnej Grecji i Rzymie w świetle pism lekarzy ówczesnych czasów i współczesnych opracowań, 2009.

3. Jarzynka Ł., Architektura użyteczności publicznej w starożytnym Rzymie na podstawie wybranych źródet i opracowań, 2009.

4. Jóźwiak D., Wróżbiarstwo w starożytnym Rzymie w świetle dzieła Cycerona „De divinatione", 2009.

5. Kujawa J., Wierzenia starożytnych Egipcjan i ich wpływ na rozwój kultury nad Nilem $w$ świetle wybranych opracowań, 2009. 
6. Lasota K., Taktyka wojenna Aten i Sparty w wojnie peloponeskiej na podstawie źródet i opracowań, 2009.

7. Borowik M., Obraz kobiety $w$ wybranych tekstach Paula Evdokimowa i Karola Wojtyty, 2009.

8. Walicka J., Percepcja starożytnych igrzysk $w$ nowożytnych $i$ wspótczesnych olimpiadach, 2009.

9. Wasilczuk K., Ostatnie pożegnanie w Starożytnej Grecji na podstawie źródet i opracowań, 2009.

10. Wilkoławska A., Obraz kobiety feministki w wybranych komediach Arystofanesa, 2009.

11. Wrochna P., Powstanie Spartakusa w świetle źródet i opracowań, 2009.

12. Ciota I., Teatr japoński jako element kultury Dalekiego Wschodu, 2010.

13. Jaroszyńska E., Piramidy egipskie jako grobowce faraonów na podstawie autorów polskich, 2010.

14. Kłoda B., Wojna domowa między Cezarem i Pompejuszem w świetle „, De bello civili libri decem (Pharsalia)" Lukana, 2010.

15. Komar J., Atlantyda w świetle XX-wiecznej literatury przedmiotu, 2010.

16. Konaszuk S., Wychowanie w Sparcie na podstawie opracowań Henri-Irénée Marrou i Lidii Winniczuk, 2010.

17. Kowalczyk O.A., Problematyka rodziny w listach Pliniusza Młodszego, 2010.

18. Lubaś K.F., Obraz życia w Cesarstwie Rzymskim za panowania Trajana w świetle korespondencji Pliniusza Młodszego, 2010.

19. Syroka J., Troska o człowieka na podstawie Przysiegi Hipokratesa, 2010.

20. Wiącek Ł., Wizerunek gejszy w kulturze japońskiej w polskojęzycznej literaturze, 2010. 